\title{
Behavioural responses of captive-born greater rheas Rhea americana Linnaeus (Rheiformes, Rheidae) submitted to antipredator training
}

\author{
Cristiano S. de Azevedo \& Robert J. Young \\ Pós-graduação em Zoologia de Vertebrados, Conservation, Ecology and Animal Behaviour Group, Pontifícia Universidade \\ Católica de Minas Gerais. Avenida Dom José Gaspar 500, Prédio 41, Coração Eucarístico, 30535-610 Belo Horizonte, Minas \\ Gerais, Brasil. E-mail: cristianoroxette@yahoo.com; robyoung@pucminas.br
}

\begin{abstract}
Human activities have been diminishing greater rhea Rhea americana (Linnaeus, 1758) populations throughout their natural distribution. The reintroductions of captive-born greater rheas have been tried but without success; since the individuals reintroduced were killed by predators. Captive-born animals that have been isolated from predators for many generations can lose their predator recognition abilities. To enhance the survival rates of the reintroduced animals, researchers are now using antipredator training techniques. We studied the response of 15 zoo-borne greater rheas to antipredator training. The animals were divided into three groups: two test groups and one control group.We ran 15 antipredator tests and four control testes with each group. Antipredator tests consisted of pairing a taxidermized predator model or a real predator (domestic dog) with a simulation of a capture procedure. Control tests consisted of presenting the predator model (jaguar) to the birds, after training but not associating it with an aversive event and recording behavioural responses. All tests were video-recorded and analysed a posteriori. Results showed that the trained rheas responded appropriately to the predators, becoming more vigilant and that there was considerable individual differences in response to antipredator training. The results demonstrated that antipredator training is effective and therefore an invaluable tool for reintroduction projects involving greater rheas. Furthermore, the methods employed in this research project should be applicable to other species of flightless birds.
\end{abstract}

KEY WORDS. Aves; classical conditioning; conservation; reintroduction; survival.

\begin{abstract}
RESUMO. Respostas comportamentais de emas cativas Rhea americana Linnaeus (Rheiformes, Rheidae) submetidas a treinamento anti-predação. As atividades humanas têm diminuído as populações de emas Rhea americana (Linnaeus, 1758) por toda sua área de distribuição. Reintroduções de emas nascidas em cativeiro têm sido tentadas, mas sem sucesso, uma vez que os indivíduos reintroduzidos são mortos por predadores. Animais nascidos em cativeiro que foram isolados de seus predadores por várias gerações podem se tornar incapacitados do seu reconhecimento. Para aumentar as taxas de sobrevivência dos animais reintroduzidos, pesquisadores têm utilizado técnicas de treinamento anti-predação. O objetivo deste trabalho foi a aplicação de treinamento anti-predação em emas nascidas em cativeiro e avaliação de suas respostas comportamentais. Foram treinadas 15 emas adultas. Os animais foram divididos em três grupos: dois grupos-teste e um grupo controle. Foram realizados 15 testes antipredação e quatro testes-controle com cada grupo. $O$ teste anti-predação consistia em parear um modelo taxidermizado de predador (onça-pintada) ou um predador real (cachorro doméstico) com uma simulação de captura. Os testescontrole consistiram na apresentação do modelo do predador (onça empalhada) às aves, depois do treinamento, mas sem a associação com o estímulo aversivo. As respostas comportamentais foram filmadas e os comportamentos anotados posteriormente. Os resultados mostraram que as emas responderam apropriadamente aos predadores, se tornando mais vigilantes, e que existem diferenças individuais evidentes em resposta ao treinamento anti-predação. Os resultados demonstraram que o treinamento anti-predação pode ser uma ferramenta valiosa para futuros projetos de reintrodução envolvendo emas. Além disso, os métodos empregados nesta pesquisa podem ser aplicados a outras espécies de aves não-voadoras.
\end{abstract}

PALAVRAS CHAVE. Aves; condicionamento clássico; conservação; reintrodução; sobrevivência.

The greater rhea, Rhea americana (Rheidae), is the largest South American bird, being distributed throughout Brazil, Argentina, Uruguay, Paraguay and southern Bolivia (Del Hoyo et al. 1992). In Brazil, it is found in central, southeast, northeast and southern regions. In Minas Gerais, Brazil, there are isolated populations, the species being locally classified as threat- 
ened with extinction (MACHADo et al. 1998). The disappearance of wild populations is due to hunting, habitat loss, destruction of eggs by agricultural machinery and crop burning (DANI 1993). The adoption of management procedures, such as reintroduction programs, is considered necessary for the maintenance of this species in their natural habitat.

A great number of reintroduction programs have not been successful in establishing viable populations (KLEIMAN 1989, Griffith et al. 1989, MacMillan 1990, BecK et al. 1994, Wolf et al. 1996): mortality caused by predation has been implicated in some cases (Bеск et al. 1991, Short et al. 1992, Miller et al. 1994), including in a previous program of greater rhea reintroduction in Minas Gerais (Ângela Faggioli, BH Zoo Biologist, pers. comm.). The major predators of greater rheas in the wild are the jaguar, Panthera onca Linnaeus, 1758; maned-wolf, Chrysocyon brachyurus Illiger, 1811; common tegu, Tupinambis teguixin Linnaeus, 1758; bush dog, Speothos venaticus Lund, 1842; some species of birds of prey; and feral dogs, Canis familiaris Linnaeus, 1758 (DANI 1993).

Recently, interest has grown in training naïve animals to recognize predators; preliminary results have been encouraging (Miller et al. 1994, Maloney \& McLean 1995, McLean et al. 1999). Substantial empirical evidence demonstrates that animals, which initially show no fear of predators, can be conditioned to respond to live and model predators (Curio 1988, Maloney \& MCLEAN 1995). Furthermore, if an animal still has the appropriated antipredator responses but does not display it when it sees a predator, antipredator training can enhance these responses making the animal respond appropriately (GRIFFIN et al. 2000).

The objective was to measure and increase the antipredator responses of captive-bred greater rheas by pairing the presentation of live (domestic dog) and taxidermically prepared models of predators (jaguar) with an aversive stimulus (simulated capture).

\section{MATERIAL AND METHODS}

\section{Animals, housing and maintenance}

The study was conducted at the Belo Horizonte Zoo, Minas Gerais, Brazil (BH Zoo). Fifteen greater rheas (eight males and seven females), all bred at BH Zoo, were studied. Birds varied in age (two to six years old), which in part reproduced the structure of wild groups (SICK 1997). Rheas were caught and handled regularly prior to the experiments.

Rheas were randomly assigned into three groups: two experimental (trained) and one control (untrained) group. Four birds composed each trained group, which were housed in enclosures $15 \mathrm{~m}$ long and $13 \mathrm{~m}$ wide. Seven birds, housed in an enclosure, $28 \mathrm{~m}$ length and $16 \mathrm{~m}$ wide, composed the control group. Unfortunately, logistical constraints at the BH Zoo meant that groups could not be balanced in terms of size or sex ratio. All groups received food and water ad libitum. Each bird received a number for identification (tattooed on the leg).

\section{Test Arena}

During experiments, the birds were held in a test arena. This was a wire-fenced enclosure (length $37.0 \mathrm{~m} \mathrm{X} 8.4 \mathrm{~m}$ wide). The fence was screened with a 2-m-high strip of opaque black plastic to isolate the birds visually from their surroundings. A circular opening of $0.3 \mathrm{~m}$ in diameter in the plastic, on one of the short sides of the enclosure allowed the observer to watch and video record the birds from a hide adjoining the fence. An additional opening of $1.5 \mathrm{~m} \mathrm{X} 1.0 \mathrm{~m}$ was located in the middle of the right long side of the enclosure and behind these was a corridor with a stage on which visual stimuli (predator models) were presented. Stimuli were fixed to a cart that was pulled by ropes through the corridor. Curtains hanging perpendicular to the enclosure screened the models from the rheas before and after presentations (Fig. 1). The test arena was divided into four squares to evaluate which regions of the enclosure were used most during antipredator training sessions. Each of the squares was divided into two areas, one near the stage (window of appearance of the predator) and the other far from this window. In total, we divided the test arena into eight different regions (in figure 1 we have only represented the four principal squares).

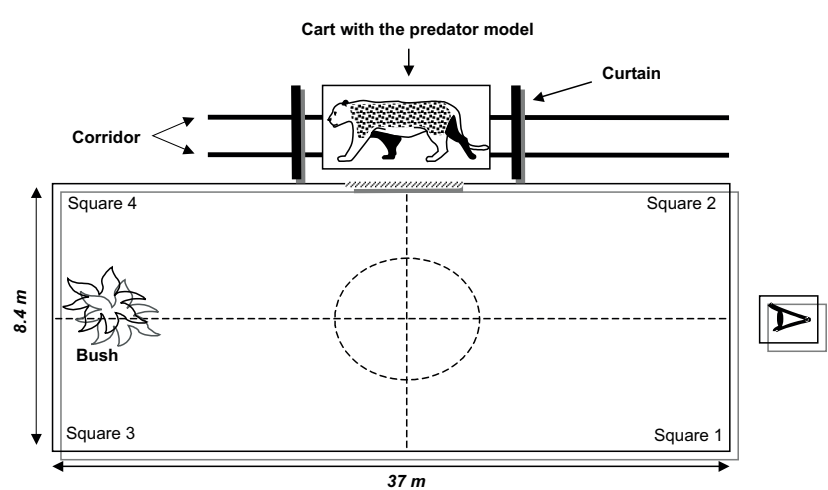

Figure 1. Plan view of the test arena. Rheas saw the predator through a window on the long side of the right fence (researcher view). The "Bush" provided the rheas with shelter. The arena was divided into squares (dash lines) to evaluate the region of the enclosure most used by the birds during trials (see text for details). Tests begun when most of the rheas were occupying the central circle. Drawing: Humberto Mello, 2004.

\section{Experimental protocol}

It were used two different predator models: a taxidermized model of a jaguar (Treatment 1), a live dog (Treatment 3), and a chair used as a control stimulus (Treatment 2) (Fig. 2).

Antipredator training sections were based on the methodology of GRIFFIN et al. (2001): the stimulus (predator) appeared to the animals for about 3-5 seconds before a human carrying a net (Fig. 3) entered the enclosure and began a simulated cap- 


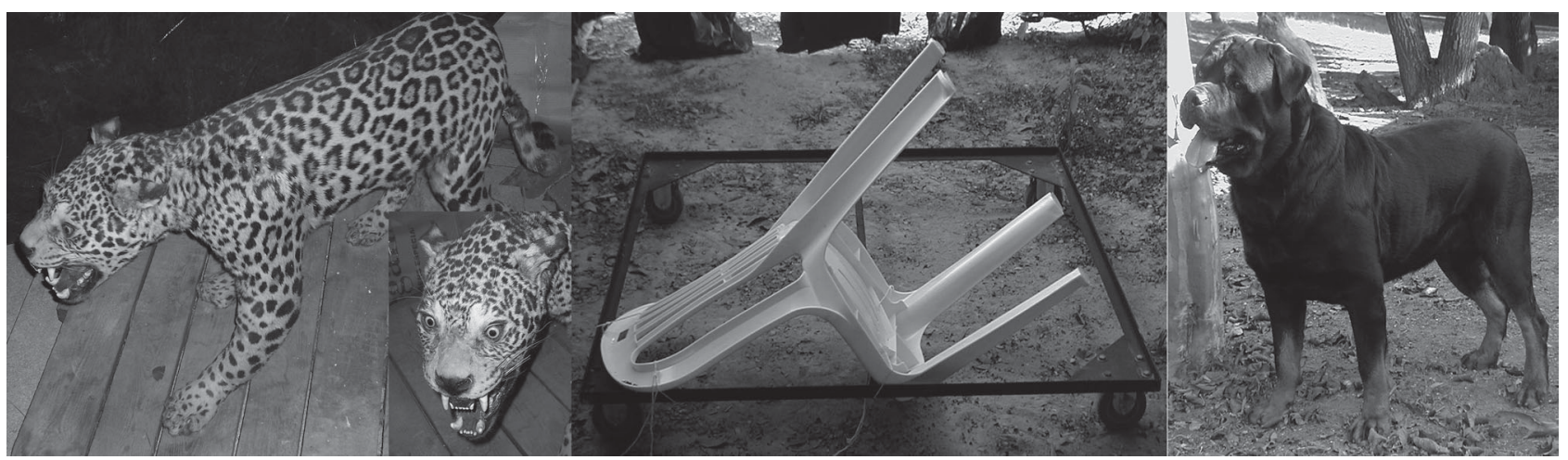

Figure 2. Models used during antipredator tests (Left: taxidermized jaguar; Middle: chair; Right: live domestic dog). Photos: Cynthia Cipreste, 2003.

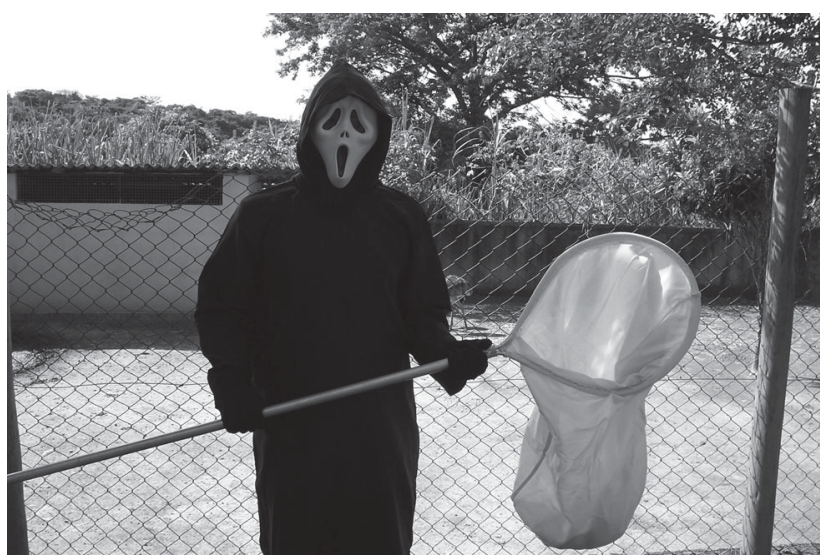

Figure 3. Chaser carrying a net. The costume had the objective of camouflaging the human silhouette. Photo: Robert Young, 2003.

ture procedure (aversive experience). In the trained groups, the appearance of the stimulus (dog or jaguar model), thus, reliably predicted the onset of the capture event. We simulated a standard capture procedure but the birds were never caught. Birds were chased back and forth four times in the enclosure along the fence while the net was held just above ground level. The human exited the arena through the hide and the stimulus was passed through view of the birds again for about 3-5 seconds. The whole conditioning procedure lasted about 60 seconds. A costume inspired by the serial killer of the movie "Scream", from Dimension Films (1996) was wore by the human during the pursuit of the rheas, which had the objective of camouflaging his silhouette. The control group was not trained. All the models were presented to the rheas in the same way but only the jaguar and the dog were paired to the aversive stimulus (simulation of a capture procedure).

Each animal received 15 training sessions, divided equally between the jaguar, the chair and the dog. Sessions were run from June to September 2003. All data were collected within seven hours of sunrise and four hours of sunset. These were ideal times to run the training sessions because rheas forage in the morning and in the late afternoon (CoDENotTi et al. 1995). Each trial lasted 18 minutes, which consisted of two minutes of filming the rheas before the presentation of the predator, the 1-minute of conditioning and 15 minutes of filming after the end of the conditioning.

\section{Control tests}

The presentation of the predator model (we used only the taxidermized jaguar) to the control group (untrained group) and the trained groups (after training) allowed us to evaluate if the behavioural responses of these rheas differed from the behavioural responses of the rheas from the trained groups. The model presentation was not paired to an aversive stimulus, and each trial lasted 18 minutes. A total of four control trials were run spread over 40 days.

\section{Data collection and statistical analyses}

Rheas were video recorded for two minutes immediately prior to stimulus (baseline), one minute during the stimulus presentation (predator or chair), and 15 minutes after the stimulus has disappeared from view. It was recorded time of the individual's reaction to the stimulus (latency) and analysed the responses of the rheas to the training sections. It was also recorded the region of the enclosure occupied by the rheas in each sampling point and the direction to where the bill was pointed (due to logistical problems, this kind of information was not collected for control group since it was tested in their home enclosure and not in the test arena like the trained groups). This type of data helped to analyse the rate of vigilance showed by the birds during the tests.

Data were collected using focal sampling with instantaneous recording of behaviour every 15 seconds. For control tests, the method used for data recording was the same of antipredator training, except for control group; in which was used scan sampling and instantaneous recording, with intervals of 15 seconds. 
The behaviours recorded during the tests were vocalizing, alert, walking, pacing, inactive, foraging, running in zigzags, running straight, squatting down, and flattening the body against the ground, hiding behind the tree, and jumping. The behaviours alert, pacing, running in zigzags, running straight, squatting down and flattening the body against the ground, jumping and hiding behind the tree were considered to indicate stress, fear, vigilance or defence. The behaviours walking, inactive, vocalizing, foraging, and other behaviours were considered to indicate that the birds were relaxed (CoDENotTi et al. 1995).

Latencies were recorded using a digital stopwatch; three measures were taken for each bird and the average resulted was used in analysis. The percentage of the number of registers in each region of the enclosure and the regions to where the bills were pointed were calculated. Behaviours were quantified and statistically analysed using Friedman non-parametrical ANOVA test.
The Tukey test was used post-hoc to compare the behavioural responses to the three different models (jaguar, chair and dog), and between treatments (trained versus not trained) for control tests. For all statistical analyses, the confidence level was 95\% $(\alpha=0.05)$.

\section{RESULTS}

\section{Antipredator training}

The behaviour categories "foraging", "squatting down and flattening the body against the ground", "jumping" and "hiding behind the tree" were excluded from statistical analysis because they were seldom or not at all registered.

Friedman analysis revealed no statistical differences in the behaviours displayed across the sequences of training trials. The differences were not significant for both trained groups. Behavioural responses of trained groups and of individual birds are given in table I.

Table I. Mean number ( \pm standard error) of behaviours of trained groups and of each bird, separated by the three treatments: (1) jaguar, (2) chair, (3) dog.

\begin{tabular}{|c|c|c|c|c|c|c|c|}
\hline \multirow{2}{*}{ Rhea } & \multirow{2}{*}{ Treatments } & \multicolumn{6}{|c|}{ Behaviours } \\
\hline & & Alert & Walking & Inactive & Pacing & Running zigzags & Running straight \\
\hline \multirow[t]{3}{*}{ Group 1} & 1 & $19.1 \pm 1.2$ & $36.5 \pm 1.4$ & $0.3 \pm 0.2$ & $21.6 \pm 1.2$ & - & $18.5 \pm 1.1$ \\
\hline & 2 & $24.2 \pm 1.3$ & $64.7 \pm 1.4$ & $0.3 \pm 0.2$ & $4.5 \pm 0.6$ & $0.1 \pm 0.1$ & $1.0 \pm 0.3$ \\
\hline & 3 & $30.1 \pm 1.4$ & $41.8 \pm 1.5$ & $0.7 \pm 0.2$ & $11.1 \pm 0.9$ & $0.2 \pm 0.1$ & $8.5 \pm 0.8$ \\
\hline \multirow[t]{3}{*}{3} & 1 & $18.3 \pm 2.3$ & $66.2 \pm 2.8$ & - & $9.3 \pm 1.7$ & - & $2.4 \pm 0.9$ \\
\hline & 2 & $31.7 \pm 2.7$ & $63.1 \pm 2.8$ & - & - & - & $0.3 \pm 0.3$ \\
\hline & 3 & $24.5 \pm 2.5$ & $57.6 \pm 2.9$ & $1.0 \pm 0.6$ & $1.0 \pm 0.6$ & - & $0.7 \pm 0.5$ \\
\hline \multirow[t]{3}{*}{4} & 1 & $6.9 \pm 1.5$ & $18.6 \pm 2.3$ & - & $43.8 \pm 2.9$ & - & $19.3 \pm 2.3$ \\
\hline & 2 & $11.4 \pm 1.9$ & $59.0 \pm 2.9$ & $0.7 \pm 0.5$ & $16.9 \pm 2.2$ & - & - \\
\hline & 3 & $14.1 \pm 2.1$ & $26.9 \pm 2.6$ & $1.0 \pm 0.6$ & $39.7 \pm 2.9$ & $0.3 \pm 0.3$ & $3.8 \pm 1.1$ \\
\hline \multirow[t]{3}{*}{5} & 1 & $31.3 \pm 2.7$ & $23.1 \pm 2.5$ & - & $4.8 \pm 1.3$ & - & $39.7 \pm 2.9$ \\
\hline & 2 & $36.9 \pm 2.8$ & $59.7 \pm 2.9$ & $0.3 \pm 0.3$ & - & - & $2.4 \pm 0.9$ \\
\hline & 3 & $47.9 \pm 2.9$ & $21.4 \pm 2.4$ & $0.3 \pm 0.3$ & $2.4 \pm 0.9$ & - & $26.9 \pm 2.6$ \\
\hline \multirow[t]{3}{*}{7} & 1 & $19.7 \pm 2.4$ & $37.9 \pm 2.9$ & $1.0 \pm 0.6$ & $28.6 \pm 2.7$ & - & $12.4 \pm 1.9$ \\
\hline & 2 & $16.9 \pm 2.2$ & $76.9 \pm 2.5$ & - & $1.0 \pm 0.6$ & $0.3 \pm 0.3$ & $1.0 \pm 0.6$ \\
\hline & 3 & $33.8 \pm 2.8$ & $61.4 \pm 2.9$ & $0.3 \pm 0.3$ & $1.4 \pm 0.7$ & $0.3 \pm 0.3$ & $2.4 \pm 0.9$ \\
\hline \multirow{3}{*}{ Group 2} & 1 & $48.7 \pm 1.5$ & $22.0 \pm 1.3$ & $0.1 \pm 0.1$ & $1.1 \pm 0.3$ & $0.5 \pm 0.2$ & $25.8 \pm 1.3$ \\
\hline & 2 & $30.3 \pm 1.4$ & $42.3 \pm 1.5$ & $1.4 \pm 0.3$ & $0.1 \pm 0.1$ & - & $5.2 \pm 0.7$ \\
\hline & 3 & $34.2 \pm 1.4$ & $23.1 \pm 1.2$ & $0.3 \pm 0.2$ & $0.6 \pm 0.2$ & $0.4 \pm 0.2$ & $25.3 \pm 1.3$ \\
\hline \multirow[t]{3}{*}{1} & 1 & $48.3 \pm 2.9$ & $24.5 \pm 2.5$ & - & $2.1 \pm 0.8$ & $0.7 \pm 0.5$ & $24.5 \pm 2.5$ \\
\hline & 2 & $43.4 \pm 2.9$ & $30.0 \pm 2.7$ & $3.1 \pm 1.0$ & - & - & $4.1 \pm 1.2$ \\
\hline & 3 & $44.8 \pm 2.9$ & $22.8 \pm 2.5$ & $0.3 \pm 0.3$ & $1.0 \pm 0.3$ & $0.1 \pm 0.6$ & $29.3 \pm 2.7$ \\
\hline \multirow[t]{3}{*}{2} & 1 & $72.4 \pm 2.6$ & $13.8 \pm 2.0$ & - & $1.0 \pm 0.6$ & $0.7 \pm 0.5$ & $9.0 \pm 1.7$ \\
\hline & 2 & $38.6 \pm 2.9$ & $16.6 \pm 2.2$ & $0.3 \pm 0.3$ & - & - & $0.7 \pm 0.5$ \\
\hline & 3 & $45.9 \pm 2.9$ & $16.2 \pm 2.2$ & $0.3 \pm 0.3$ & - & - & - \\
\hline \multirow[t]{3}{*}{6} & 1 & $60.3 \pm 2.9$ & $32.8 \pm 2.8$ & $0.3 \pm 0.3$ & $0.3 \pm 0.3$ & - & $4.5 \pm 1.2$ \\
\hline & 2 & $23.8 \pm 2.5$ & $64.8 \pm 2.8$ & $1.0 \pm 0.6$ & - & - & - \\
\hline & 3 & $43.8 \pm 2.9$ & $52.1 \pm 2.9$ & $0.7 \pm 0.5$ & $0.3 \pm 0.3$ & $0.7 \pm 0.5$ & $0.7 \pm 0.5$ \\
\hline \multirow[t]{3}{*}{8} & 1 & $5.1 \pm 1.5$ & $15.5 \pm 2.4$ & - & $0.9 \pm 0.6$ & $0.4 \pm 0.4$ & $75.0 \pm 2.8$ \\
\hline & 2 & $15.5 \pm 2.1$ & $57.9 \pm 2.9$ & $1.0 \pm 0.6$ & $0.3 \pm 0.3$ & - & $15.9 \pm 2.2$ \\
\hline & 3 & $2.4 \pm 0.9$ & $1.4 \pm 0.7$ & - & $1.0 \pm 0.6$ & $0.7 \pm 0.5$ & $71.4 \pm 2.7$ \\
\hline
\end{tabular}


The behaviour walking was the most observed in trained group one, with all models. The second most observed behaviour was alert. Fear behaviours, like pacing and running straight were observed during the trials run with the jaguar and the dog; for the chair, these behaviours were rarely recorded.

For trained group two, the behaviour alert occurred most in treatment one and three (jaguar and dog, respectively), followed by running straight. In treatment two, walking was the most recorded behaviour. Birds individually did not show any definite behaviour pattern.

The results of Friedman tests are shown in table II. For trained group one, the behaviours that differed statistically between the three treatments were alert, walking, pacing, running in zigzags and running straight. Tukey tests revealed that alert behaviour occurred more in treatment three (dog); walking occurred more during the tests run with the chair (treatment two); pacing and running straight were more recorded during treatments one and three, and running in zigzags occurred more in treatment three (dog).

Table II. Friedman tests for the trained groups.

\begin{tabular}{|c|c|c|c|c|c|c|}
\hline & \multirow{2}{*}{ Alert } & \multirow[t]{2}{*}{ Walking } & \multirow[t]{2}{*}{ Inactive } & \multirow{2}{*}{ Pacing } & \multicolumn{2}{|c|}{ Running } \\
\hline & & & & & Zigzags & Straight \\
\hline Group 1 & $28.6^{\star \star \star}$ & $139.2^{* * *}$ & 4.4 & $86.9^{* * *}$ & $6.9^{*}$ & $220.2^{* \star \star}$ \\
\hline Group 2 & $85.5^{\star * \star}$ & $148.6^{\star \star \star}$ & $15.3^{* *}$ & $24.1^{\text {***}}$ & $7.4^{\star}$ & $329.2^{\star \star \star}$ \\
\hline
\end{tabular}

For trained group two, all behaviours differed statistically between the three treatments. Tukey tests revealed that vigilant and defence behaviours, like alert, running straight and pacing were more realized during tests with the jaguar and the dog. Relaxed behaviours, like walking, on the contrary, were more expressed during the control trials with the chair. Again, each bird responded differently depending on the model used.

Trained birds pointed their bills most to region four (the front of the enclosure), although some individuals pointed more towards region two (predator area) and for region one (back of the enclosure). The enclosure area most used by the birds during the trials was region three (back, side contrary to the predator appearance) (Tab. III).
Latencies to respond to the predator are show in table IV. Trained group two responded to the stimuli faster than trained group one, being this difference statistically significant $(\mathrm{p}<0.005)$. For both trained groups, the jaguar was responsible for the fastest response (1.62 seconds for group one; 0.61 seconds for group two); for group one, the slowest response was for the dog, and for group two, the slowest response was attributed to the chair.

Table IV. Latency of the trained groups to respond to the three different models used during antipredator trials (time in hundredth seconds).

\begin{tabular}{cccc}
\hline \multirow{2}{*}{ Rhea } & \multicolumn{3}{c}{ Treatments } \\
\cline { 2 - 4 } & Jaguar & Chair & Dog \\
\hline Group 1 & $162.0 \pm 11.2$ & $169.0 \pm 8.2$ & $223.9 \pm 6.8$ \\
Group 2 & $61.4 \pm 1.8$ & $112.7 \pm 4.2$ & $100.1 \pm 4.2$ \\
\hline
\end{tabular}

\section{Control tests}

The behaviours displayed by the rheas of the control group differed statistically from the behaviours recorded for the two trained groups (Tab. V). Only the behaviour running straight was more expressed by trained group one; all the others were more expressed by the control group.

Tukey tests showed that during control tests, rheas of trained groups behave apprehensively, displaying behaviours such as alert and running straight more than the other behaviours. The control group had a mixture of responses, some birds behaved calmly and others behaved nervously. Calm and nervous behaviours appeared in all tests, almost at the same rate but in general, birds behaved in a more tranquil manner (Tab. V).

The groups of birds differed in their latencies (measured in hundredths of seconds) of responses to the predator model: group 2 responded the quickest $(52.7 \pm 16.2$, mean \pm SEM), then group $1(73.9 \pm 29.8$, mean \pm SEM) and finally the control group $(114.5 \pm 90.8$, mean \pm SEM $)$.

\section{DISCUSSION}

The antipredator training applied to the greater rheas was effective, with the birds behaving appropriately to the preda-

Table III. Areas used and directions of bill for the trained groups and each bird individually on the test yard during antipredator trials. Percentage of the number of records in each area and each bill direction: (I) back of the enclosure; (II) predator area; (III) area opposite spatially to predator; (IV) front of the enclosure. Areas: (1) front of the enclosure, contrary to predator; (2) front of the enclosure, contrary to predator; (3) back of the enclosure, contrary to predator; (4) back of the enclosure, predator area; (5) square 1, in front of the window of predator appearance; (6) square 2, in front of the window of predator appearance; (7) square 3, in front of the window of predator appearance; (8) square 4 , in front of the window of predator appearance.

\begin{tabular}{|c|c|c|c|c|c|c|c|c|c|c|c|c|}
\hline \multirow{2}{*}{ Rhea } & \multicolumn{4}{|c|}{ Bill directions (\%) } & \multicolumn{8}{|c|}{ Areas of the enclosure (\%) } \\
\hline & $\mathrm{I}$ & II & III & IV & 1 & 2 & 3 & 4 & 5 & 6 & 7 & 8 \\
\hline Group 1 & 31.58 & 12.55 & 17.05 & 38.82 & 2.87 & 0.43 & 71.01 & 5.60 & 5.09 & 0.11 & 14.80 & 0.09 \\
\hline Group 2 & 36.36 & 9.76 & 13.13 & 40.75 & 33.31 & 7.54 & 36.56 & 0.70 & 9.85 & 0.32 & 11.57 & 0.15 \\
\hline
\end{tabular}

Revista Brasileira de Zoologia 23 (1): 186-193, março 2006 
Table V. Mean number of observations, standard error and Friedman results for the behaviours presented by the three groups during control tests.

\begin{tabular}{|c|c|c|c|c|c|}
\hline Behaviour & Group 1 & Group 2 & Control & Friedman & $p$-value \\
\hline Alert & $24.5 \pm 0.70$ & $37.6 \pm 0.80$ & $144.0 \pm 8.6$ & 1257.0 & $<0.01$ \\
\hline Walking & $47.6 \pm 0.90$ & $29.3 \pm 0.80$ & $206.5 \pm 9.9$ & 1721.5 & $<0.01$ \\
\hline Foraging & $0.7 \pm 0.04$ & $0.1 \pm 0.06$ & $1.7 \pm 0.9$ & 84.9 & $<0.01$ \\
\hline Pacing & $12.4 \pm 0.60$ & $0.6 \pm 0.01$ & $44.0 \pm 5.1$ & 649.2 & $<0.01$ \\
\hline Running straight & $9.3 \pm 0.50$ & $18.6 \pm 0.70$ & $35.8 \pm 4.5$ & 793.0 & $<0.01$ \\
\hline Other behaviours & - & $0.4 \pm 0.09$ & $3.0 \pm 1.5$ & 137.8 & $<0.01$ \\
\hline
\end{tabular}

For all Friedman tests D.F. $=2$.

tor models, which can be confirmed by the increase of vigilance and defence behaviours and the suppression of relaxed behaviours. Vigilance behaviours, like alert and defence behaviours, like running straight and running in zigzags were much more prominent during trials with the jaguar and the dog; relaxed behaviours, like walking, foraging and inactive were much more prominent during the trials with the chair.

Training trials with the jaguar model increased antipredator responses (increase in vigilance and defence behaviours); trials with the live dog also increased the exhibition of vigilance and defence behaviours, although less effectiveness than the jaguar. We have three hypotheses for this difference: firstly, the domestic dog used in the tests was harder to see than the jaguar, since it was black, the contrast between the dog and the wall behind it (the colour of the wall was black) probably made the dog less conspicuous than the jaguar; secondly, the noise of the cart helped the birds to predict the appearance of the jaguar model; the dog, however, was not presented to the birds using the cart, so birds could not predict the time of its appearance (this hypothesis is also supported by the latency recorded for the groups; both groups responded faster to the jaguar model than to the domestic dog); thirdly, domestic dogs have not been predators of rheas during their evolutionary history (Del Hoyo et al. 1992, DANI 1993). It seemed that rheas simply did not recognize the dog as a predator, therefore responded slower to it during antipredator trials, despite the fact that dogs possess predator characteristics, such as eyes on the front of the face, quadruped body position, etc.

Training trials using the chair as the model revealed that rheas were not responding to the cart noise but they were responding to the predator models. Birds learned that the predator appearance predicted the pursuit by the man and not the cart noise predicted the persecution. Rheas responded to the chair with relaxed behaviours and not appropriate antipredator behaviours (e.g., vigilance).

We did not find any statistical difference between subsequent training sessions; birds responded equally to the predators during all trials. This result indicated that the time of isolation from predators (two generations) was not sufficient to eliminate all species-specific defence reaction (SSDR) precur- sors, allowing an increase in antipredatory reactions with the use of classical conditioning techniques (GrifFin et al. 2000). A great number of experiments using animal conditioning to improve predator recognition have showed that an adequate learning response occurs with only one or two exposures to the predator stimuli (Magurran 1989, Suboski et al. 1990, Chivers \& SMith 1994a, b, Chivers et al. 1995, Maloney \& McLean 1995, Curio 1998, McLeAn et al. 1999). From our results we conclude that the number of training sessions we used (five with each model) could probably be reduced; however, the ideal number of training sessions, should be defined experimentally.

Rheas of both trained groups most occupied the area farthest from the predator. Region one was also used because rheas, when in pursuit, ran back and forth inside the enclosure (due to the limitation of space). Sometimes we observed rheas approaching the area where the predator appeared, apparently looking for the models. Lima \& Dill (1990) reported that some animals instead of running away immediately when they encounter a predator, they approach it and examine it. According to Pitcher et al. (1986), this kind of predator inspection is widespread throughout vertebrates. Predator inspection is reported for passerine birds, such as Junco hyemalis (Linnaeus, 1758) and Spizella arborea (Wilson, 1810) (FrankLIN \& Lima 2001). The benefits of predator inspection are predator localization, the collection of information about the predator's motivation (i.e., the risk of attack) and to diminish the chance of being attacked by showing to the predator that it has been detected.

Rheas pointed their beaks mostly to regions one (front of the test arena) and four (back of the test arena). According to Wright \& BowMAKer (2001), rheas and ostriches have a monocular vision field in each eye that extends for $155^{\circ}$ and probably functions to alert them about dangers on the horizon. They also have a binocular field of vision, located in front of the bill, which extends vertically for $80^{\circ}$ and covers an area of $20^{\circ}$ in width. This small binocular field of vision would be used primarily to collect food items on the ground (MARTIN \& KATZIR 1995,1999 ), the principal feeding method of this species (PerRINs $\&$ Middleton 1998). Staying with their beaks pointed to the front of the enclosure, allowed the birds to observe region two (predator area); however, some rheas changed the direction of

Revista Brasileira de Zoologia 23 (1): 186-193, março 2006 
their bill frequently, which is a characteristic of vigilant birds. The constant head movements permit the birds to scan larger areas, increasing their chance of detecting a predator.

During our testing procedures we noted considerable individual variation in the development of antipredator responses (see Tab. I), this variation may have an influence on survival once animals are released into the wild. Therefore, we suggest investigations of this variation through personality tests (see FEAvEr et al. 1986), which may indicate individuals that are worth training and releasing. We have shown that our animals appeared to have developed appropriate antipredator responses due to our training programme: the next important step is the release of trained and untrained animals to the wild, and the monitoring of their survival rates.

This kind of training could be a useful tool for reintroduction programmes of other threatened flightless bird species, since it increases appropriate behavioural responses to predators. Training sessions should also be run for different animal species to evaluate if antipredator tests are effective for species other than greater rheas.

\section{ACKNOWLEDGEMENTS}

We are grateful to Dr Andrea Griffin for her valuable suggestions about the methodologies used in this research; to $\mathrm{BH}$ Zoo for the permission to use their animals; to the Museu de Ciencias Naturais da PUC-Minas for the loan of the jaguar model; to Ângela Bernadete Faggioli and the staff of Bird Section for their help and suggestions. We also would like to thank Laura, Marcos and Luciana for their assistance during the training sessions. This study was undertaken while Cristiano Schetini de Azevedo was in receipt of a postgraduate scholarship from CAPES (Coordenação de Aperfeiçoamento de Pessoal de Nível Superior). The research conducted in this article conforms with animal care laws in Brazil and was approved by the BH Zoo's Ethical Committee.

\section{REFERENCES}

Beck, B.B.; D.G. Kleiman; J.M. Dietz; I. Castro; C. Carvalho; A. Martins \& B. Rettberg-Beck. 1991. Losses and reproduction in reintroduced golden lion tamarins Leontopithecus rosalia. Dodo, Jersey, 27: 50-61.

Beck, B.B.; L.G. Rapaport; M.R. Stanley Price \& A.C. Wilson. 1994. Reintroduction of captive-born animals, p. 265-286. In: P.I.S. Olney; G.M. Mace \& A.T.C. Feistner (Eds). Creative Conservation. London, Chapman \& Hall, 32+517p.

Chivers, D.P. \& R.J.F. Sмith. 1994a. The role of experience and chemical alarm signalling in predator recognition by fathead minnows (Pimephales promelas). Journal of Fish Biology, Oxford, 44: 273-285.

Chivers, D.P. \& R.J.F. Smith. 1994b. Fathead minnows, Pimephales promelas, acquire predator recognition when alarm substance is associated with the sight of unfamiliar fish. Animal Behaviour, Nottingham, 48: 597-605.
Chivers, D.P.; G.E. Brown \& R.J. Smith. 1995. Acquired recognition of chemical stimuli from pike, Esox lucius, by brook sticklebacks, Culaea inconstans (Osteichthyes, Gasterosteidae). Ethology, Oxford, 99: 234-242.

Codenotti, T.L.; D. Beninca \& F. Alvarez. 1995. Etograma y relacion de la conducta con el habitat y con la edad en el ñandú. Doñana, Acta Vertebrata, Sevilla, 22: 65-86.

CuRIo, E. 1988. Cultural transmission of enemy recognition by birds, p. 75-97. In: T.R. Zental \& B.G. Galef JR. (Eds). Social Learning: psychological and biological perspectives. New Jersey, Hilldalf, 368p.

CuRIO, E. 1998. Behavior as a tool for management: intervention for birds, p. 163-187. In: CARO, T. (Ed.). Behavioral Ecology and Conservation Biology. United Kingdom, Oxford University Press, 480p.

DANI, S. 1993. A ema Rhea americana. Belo Horizonte, Fundação Acangaú, 136p.

Del Hoyo, J.; A. Elliot \& J.A. Sargatal. 1992. A Handbook of the Birds of the World. Barcelona, Lynx Editions, vol. 1, 696p.

Feaver, J.; M.T. Mendl \& P. Bateson. 1986. A method for rating the individual distictiveness of domestic cats. Animal Behaviour, Nottingham, 34: 1016-1025.

FrankLIN, W.E. \& S.L. LimA. 2001. Laterality in avian vigilance: do sparrows have a favourite eye? Animal Behaviour, Nottingham, 62: 879-885.

Griffith, B.J.; M. Scott; J.W. Carpenter \& C. Reed. 1989. Translocation as a species conservation tool: status and strategy. Science, Washington, 245: 477-480.

Griffin, A.S.; D.T. Blumstein \& C.S. Evans. 2000. Training captive bred and translocated animals to avoid predators. Conservation Biology, Malden, 14: 1317-1326.

Griffin, A.S.; C.S. Evans \& D.T. Blumstein. 2001. Learning specificity in acquired predator recognition. Animal Behaviour, Nottingham, 62: 577-589.

Kleiman, D.G. 1989. Reintroduction of captive mammals for conservation: guidelines for reintroducing endangered species into the wild. Bioscience, Washington, 39: 152-161.

LiMA, S.L. \& I.M. DilL. 1990. Behavioural decisions made under the risk of predation: a review and prospectus. Canadian Journal of Zoology, Toronto, 82: 216-223.

Machado, A.B.M.; G.A.B. Fonseca; R.B. Machado; L.M.S. Aguiar \& L.V. Lins. 1998. Livro Vermelho das Espécies Ameaçadas de Extinção da Fauna de Minas Gerais. Belo Horizonte, Fundação Biodiversitas, 605p.

Macmillan, B.W.H. 1990. Attempts to re-establish wekas, brow kiwis and red-crowned parakeets in the waitakere rangers. Notornis, Wellington, 37: 45-51.

MagurRAn, A.E. 1989. Acquired recognition of predator odour in the European minnow (Phoxinus phoxinus). Ethology, Oxford, 82: 216-223.

Maloney, R.F. \& I.G. McLean. 1995. Historical and experimental learned predator recognition in free-living New Zealand robins. Animal Behaviour, Nottingham, 50: 1193-1201. 
Martin, G.R. \& G. Katzir. 1995. Visual fields in ostriches. Nature, London, 374: 19-20.

Martin, G.R. \& G. Katzir. 1999. Visual fields in short-toed eagles, Circaetus gallicus (Accipitridae), and the function of binocularity in birds. Brain, Behaviour \& Evolution, Austin, 53: 55-66.

Mclean, I.G.; C. Holzer \& J.S. Strudholme. 1999. Teaching predator-recognition to a naive bird: implications for management. Biological Conservation, Amsterdam, 87: 123-130.

Miller, B.; D. Biggins; L. Honebury \& A. Vargas. 1994. Reintroduction of the black-footed ferret (Mustela nigripes), p. 455-464. In: P.J.S. OlneY; G.M. Mace \& A.T.C. FeIstner (Eds). Creative Conservation. London, Chapman \& Hall, $32+517 p$.

Perrins, C.M. \& A.L.A. Middleton. 1998. The Encyclopaedia of Birds. New York, Facts of File, 16+63p.

Pitcher, T.J.; D.A. Green \& A.E. Magurran. 1986. Dicing with death: predator inspection behaviour in minnow shoals.
Journal of Fish Biology, Oxford, 28: 439-448.

Short, J.; S.D. Bradshaw; J. Giles; R.I.T. Prince \& G.R. Wilson. 1992. Reintroduction of macropods (Marsupialia: Macropoidea) in Australia: a review. Biological Conservation, Amsterdan, 62: 189-204.

SICK, H. 1997. Ornitologia Brasileira. Rio de Janeiro, Editora Nova Fronteira, 862p.

Suboski, M.D.; S. Bain; A.E. Carty; L.M. McQuoid; M.I. Seelen \& M. Seifert. 1990. Alarm reaction in acquisition and social transmission of simulated-predator recognition by zebra danio fish (Brachydanio rerio). Journal of Comparative Psychology, Washington, 104: 101-112.

Wolf, C.M.; B. Griffith; C. Reed \& S.A. Temple. 1996. Avian and mammalian translocations: an update and reanalyzes of 1987 survey data. Conservation. Biology, Malden, 10: 1142-1154.

WRIGHT, M.W. \& J.K. BOWMAKER. 2001. Retinal photoreceptors of paleognathous birds: the ostrich (Struthio camelus) and rhea (Rhea americana). Vision Research, San Diego, 41: 1-12.

Received in 15.III.2005; accepted in 03.II.2006. 